\title{
Cyclization of a carbon-centered radical derived from oxaziridine cleavage
}

\author{
Yoshinosuke Usuki, Xin Peng, Belgin Gülgeze, Shankar Manyem, and Jeffrey Aubé* \\ Department of Medicinal Chemistry, 1251 Wescoe Hall Drive, Room 4070, Malott Hall, \\ University of Kansas, Lawrence, KS 66045-7582, USA \\ E-mail: jaube@ku.edu
}

\section{Dedicated with admiration to Professor Armand Lattes}

\begin{abstract}
Treatment of an oxaziridine with low-valent iron or copper salts generates a carbon-centered radical able to cyclize onto an appended olefin.
\end{abstract}

Keywords: Oxaziridine, single-electron transfer, beta-scission, radical cyclization

\section{Introduction}

Oxaziridines undergo a wide variety of chemical transformations including rearrangement and atom transfer reactions. ${ }^{1}$ Oxaziridines have long been known to react stoichiometrically with low-valent metals such as Fe(II) via single-electron transfer (SET) pathways, affording nitrogen radical/oxygen-anion (or hydroxyl if the reaction is run in an acidic medium) pairs that undergo different secondary reaction pathways depending on the structure of the oxaziridine. ${ }^{2}$ Many of these products were proposed to result from $\beta$-scission of the nitrogen radical to afford a carboncentered radical (Scheme 1). ${ }^{2 \mathrm{a}}$ The existence of $\mathrm{R}_{2} \bullet$ has generally been assumed based on the isolation of products consistent with traditional radical processes such as hydrogen atom abstraction, disproportionation, dimerization, ${ }^{2 \mathrm{c}}$ and the ability to initiate redox alkene polymerization. $^{2 \mathrm{~b}}$ Addition reactions of $\mathrm{R}_{2} \bullet$ to electron-poor heterocycles, ${ }^{2 \mathrm{e}, \mathrm{f}} \mathrm{NO},{ }^{2 \mathrm{~d}}$ and an $\mathrm{Fe}(\mathrm{III})$-complexed acetylacetate ligand ${ }^{2 \mathrm{i}}$ have also been cited as evidence for $\mathrm{C}$-radical formation in these processes. 


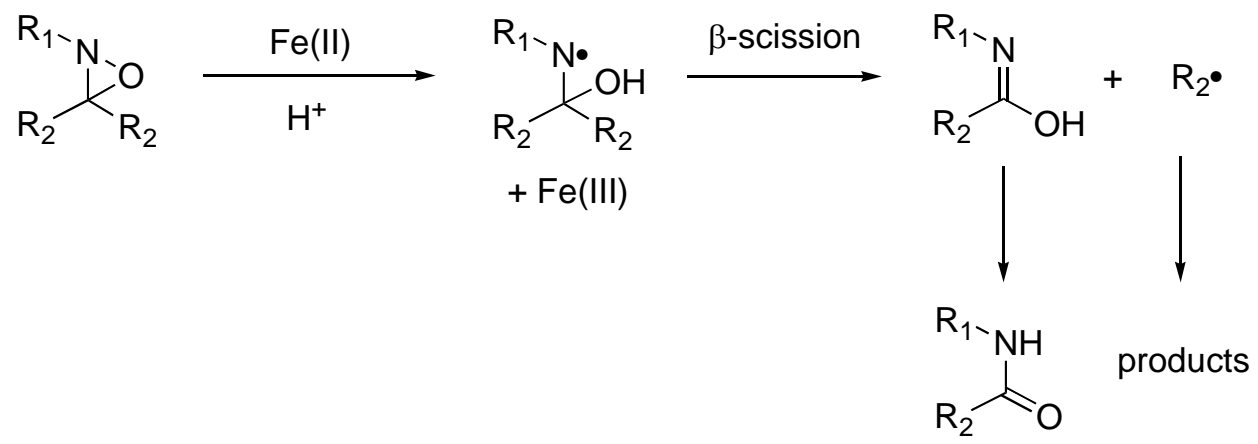

\section{Scheme 1}

The observation of 5-exo-trig cyclizations is considered strong evidence for the intermediacy of radicals ${ }^{3}$ and a powerful synthetic tool besides. ${ }^{4}$ In this article, we disclose the deliberate generation of a carbon-centered radical via oxaziridine SET and $\beta$-scission using catalytic quantities of a low-valent metal salt under neutral conditions and the cyclization of the resulting radical onto an appended olefin.

\section{Results and Discussion}

We have previously examined the SET reactions of 3-aryl oxaziridines using catalytic amounts of a soluble $\mathrm{Cu}(\mathrm{I})$ salt in refluxing THF (eq 1). ${ }^{5}$ Following formation of a putative nitrogen radical/oxygen-anion pair, a complex series of steps led to either pyrroline (1, eq 1) or azidirine (not shown); both of these products were proposed to result from nitrogen radical addition to the olefin followed by migration of the phenyl $\left(\mathrm{N}-\mathrm{CH}\left(\mathrm{CH}_{3}\right) \mathbf{P h}\right)$ group or rearrangement. ${ }^{5 a}$ Subsequent attempts to extend this chemistry to oxaziridines bearing a carbomethoxy substituent at C-3 failed, leading instead to the isolation of amide (2, eq 1). ${ }^{5 \mathrm{~b}}$ The formation of amide is consistent with the preferential $\beta$-scission route as shown in Scheme 1 and suggests that the formation of pyrroline is contingent on the presence of a C-3 substituent unable to afford a stable radical upon homolysis.

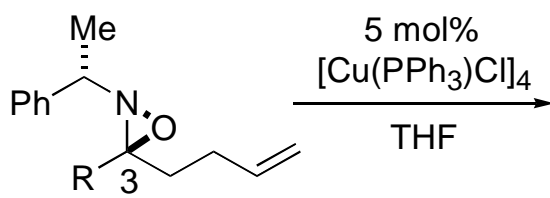

$\mathrm{R}=\operatorname{aryl}$

$\mathrm{R}=\mathrm{CO}_{2} \mathrm{Me}$

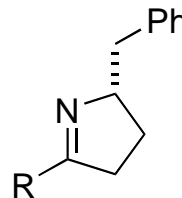

1

40-70\% not observed<smiles>C=CCCC(=O)NC(C)c1ccccc1</smiles>

2

not observed

$85 \%$

(eq 1) 
To test this, a series of oxaziridines 3-7 bearing different alkyl substituents at C-3 were prepared and subjected to treatment with $5 \mathrm{~mol} \%$ of $\left[\mathrm{Cu}\left(\mathrm{PPh}_{3}\right) \mathrm{Cl}\right]_{4}$ in refluxing THF (eq 1 and Table 1). Throughout this study, oxaziridines were prepared by condensing a ketone with an amine in toluene at reflux and treating the crude solution of imine thus made with $m$-CPBA at $78{ }^{\circ} \mathrm{C}$. ${ }^{1,5}$ Except for entries 1, 3, and 4, the oxaziridines in Table 1 were obtained and used as mixtures of stereoisomers. The relative amounts of pyrroline 1 vs. amide (usually 2 ) depended on the nature of the $\mathrm{C}-3$ substituent. In particular, the oxaziridines bearing a radical-stabilizing alkyl group at this position furnished the amide exclusively (entries 3-5), whereas when $\mathrm{R}=\mathrm{Ph}$, none of this product was obtained (entry 1). These data are consistent with a mechanism shown in Scheme 1, with only $\mathrm{R}$ groups able to afford a reasonably stable radical undergoing $\beta$ cleavage.

Oxaziridine 4 derived from a methyl ketone (entry 2) was about midway between these extremes; in fact, $N$-acetyl- $\alpha$-methylbenzylamine 9 , and not amide 2 , was the $\beta$-scission product observed in this case because loss of the 3-butenyl radical should be favored relative to Me•. The pyrroline $\mathbf{8}$ and amide $\mathbf{9}$ obtained in this case could not be separated and, hence, $\mathbf{8}$ was isolated as the pivaloyl amide $\mathbf{1 0}$ after treating the reaction mixture with pivaloyl chloride. The observed variations in ratios of 1 and 2 could not be explained based solely on the relative rates of $\beta$ fragmentation for the $\mathrm{R}$ groups (collected in Table 1). Additionally, no definitive information regarding the nature of the departing group or its fate could be inferred from these experiments (no attempt was made to isolate the non-amide products of these reactions).

Table 1. Effect of C-3 substituent on oxaziridine decompositions

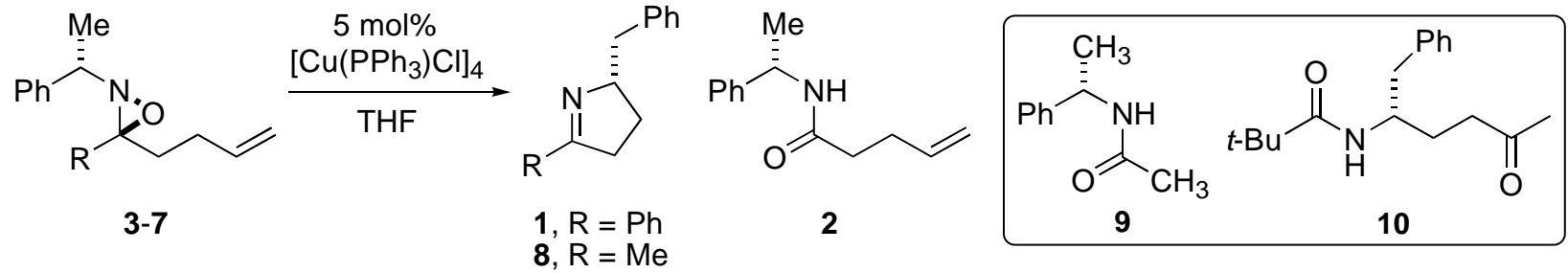

\begin{tabular}{|c|c|c|c|c|c|}
\hline \multirow{2}{*}{ Entry } & \multirow{2}{*}{$\mathrm{R}$} & \multirow{2}{*}{ Compound } & \multirow{2}{*}{$\mathrm{k}_{\mathrm{rel}}^{\mathrm{a}, 6}$} & \multicolumn{2}{|c|}{ Isolated yield $(\%)$} \\
\hline & & & & Cyclization product & Cleavage product \\
\hline 1 & $\mathrm{Ph}-$ & 3 & 23 & $66(\mathbf{1})$ & - \\
\hline 2 & $\mathrm{CH}_{3}-$ & 4 & 1 & $21(\mathbf{1 0})$ & $44(9)$ \\
\hline 3 & 3-butenyl & 5 & $100^{\mathrm{b}}$ & - & $76(2)$ \\
\hline 4 & $\left(\mathrm{CH}_{3}\right)_{2} \mathrm{CH}-$ & 6 & 3,600 & - & $89(2)$ \\
\hline 5 & $\mathrm{PhCH}_{2-}$ & 7 & 11,900 & - & $57(2)^{c}$ \\
\hline
\end{tabular}

(a) Relative rates of fragmentation $\left(\mathrm{s}^{-1}\right)$ of $\mathrm{RC}\left(\mathrm{CH}_{3}\right)_{2} \mathrm{O} \bullet$ radicals at $40{ }^{\circ} \mathrm{C}$. (b) Data for $\mathrm{CH}_{3} \mathrm{CH}_{2} \bullet$ used. (c) Based on $28 \%$ recovered oxaziridine. 
We considered the possibility of generating radicals that could be utilized in further radical processes. Accordingly, oxaziridine 12 (see Scheme 2 for structures) was synthesized in the expectation that it would undergo $\beta$-scission efficiently due to the production of a benzylic radical in so doing. An achiral amine was used to minimize complications in product analysis resulting from stereoisomer formation. Indeed, treatment with a variety of $\mathrm{Cu}(\mathrm{I})$ and $\mathrm{Fe}(\mathrm{II})$ salts in refluxing THF led smoothly to the formation of products 13a, 13b, and 14 resulting from cyclization of the carbon-centered radical. As seen in Table 2, all of the soluble catalysts used gave comparable results in terms of yield and product ratio.

Table 2. Results of cyclization experiments using 12.

\begin{tabular}{cccc}
\hline Entry & Catalyst & Combined yield (\%) & 13a : 13b : 14 \\
\hline 1 & {$\left[\mathrm{Fe}(\mathrm{bpy})_{3}\right]\left(\mathrm{PF}_{6}\right)_{2}$} & 71 & $21: 68: 11$ \\
2 & $\mathrm{FeBr}_{2}$ & 60 & $18: 68: 14$ \\
3 & {$\left[\mathrm{Cu}(\mathrm{bpy})\left(\mathrm{PPh}_{3}\right)\right] \mathrm{Cl}$} & 67 & $21: 73: 6$ \\
4 & {$\left[\mathrm{Cu}\left(\mathrm{CH}_{3} \mathrm{CN}\right)_{4}\right] \mathrm{PF}_{6}$} & 76 & $20: 70: 10$ \\
5 & {$\left[\mathrm{Cu}\left(\mathrm{PPh}_{3}\right) \mathrm{Cl}\right]_{4}$} & 66 & $19: 72: 9$ \\
\hline
\end{tabular}

aDetermined by $500 \mathrm{MHz}{ }^{1} \mathrm{H}-\mathrm{NMR}$ integration.

Our proposed mechanism is depicted in Scheme 2. Cyclopentanes 13a and 13b result from addition of the benzylic radical to the olefin in a 5-exo-trig manner followed by hydrogen atom abstraction from a molecule of THF. ${ }^{7}$ In the similar cyclization of 1-phenylhexen-5-yl radical investigated by Walling, the trans-cyclopentane 13b was obtained as the only product. ${ }^{8}$ In our case, 13b was the major product in accord with the Beckwith-Houk model. ${ }^{9}$ The decreased diastereoselectivity may be related to the changes in solvent polarity or the possibility that the cyclization is occurring inside the solvent cage. The production of $\mathbf{1 4}$ is attributed to the oxidative addition of the initially formed methylene radical into the phenyl group; such additions are commonly observed ${ }^{10}$ and appeared in the mechanism originally proposed for the formation of $1 .{ }^{5}$ It seems reasonable that $\mathrm{Cu}(\mathrm{I})$ is regenerated via SET from the amide anion to the $\mathrm{Cu}(\mathrm{II})$ formed in the first step (shown in Scheme 2 as an ion pair for book-keeping purposes). 
<smiles>C=CCCCC(C(=N)c1ccccc1)C(C)=O</smiles>

11<smiles>C=CCCCC(c1ccccc1)C1(C)ON1c1ccccc1</smiles>

12<smiles>C=CCCCC(c1ccccc1)C(C)(OCC)N(C)Cc1ccccc1</smiles><smiles>C[C@@H]1CCC[C@H]1P</smiles>

$13 a$<smiles>[CH][C@@H]1CCC[C@H]1C</smiles>

$13 b$<smiles>C[C@@H]1CCCC1P</smiles>

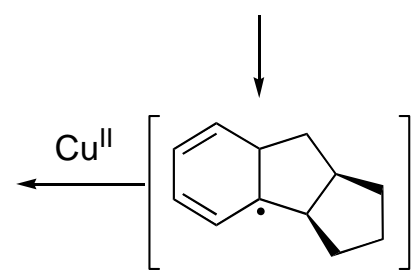<smiles>C/C(=N/c1ccccc1)O[Na]</smiles><smiles>[13CH3]</smiles><smiles>CC(=O)NC(c1ccccc1)c1ccccc1</smiles>

14

\section{Scheme 2}

Two aspects of these reactions are noteworthy. First, the observation of cyclization products from 12 constitutes good evidence that the initially formed nitrogen-centered radical actually undergoes $\beta$-scission to eject a carbon-centered radical. Second, the use of catalytic amounts of soluble $\mathrm{Fe}(\mathrm{II})$ and $\mathrm{Cu}(\mathrm{I})$ salts for initiating oxaziridine SET under neutral conditions is quite mild and synthetically attractive relative to the original techniques used for such reactions. ${ }^{2}$ Although further studies will be necessary to establish the generality of this process, the recognition that oxaziridines are readily accessible from the corresponding ketones suggests that the overall sequence of $\mathbf{1 1} \rightarrow \mathbf{1 2} \rightarrow$ radical may constitute an interesting approach to a decarbonylative method for carbon radical generation under mild, catalytic conditions. 


\section{Experimental Section}

General Procedures. THF was freshly distilled from sodium-benzophenone and degassed by multiple freeze-thaw cycles at $<0.5 \mathrm{~mm} \mathrm{Hg} .{ }^{1} \mathrm{H}$ and ${ }^{13} \mathrm{C}$ NMR spectra were recorded on a 500 MHz NMR spectrometer (at 500 and $125.5 \mathrm{MHz}$, respectively) or on a $300 \mathrm{MHz}$ machine (at 300 and $75.6 \mathrm{MHz}$, respectively). All NMR samples were dissolved in deuteriochloroform, and chemical shifts are given in parts per million (ppm) relative to the internal standard tetramethylsilane (TMS). Optical rotations were measured on a Perkin-Elmer 241 polarimeter, and concentrations are reported in $\mathrm{g} / 100 \mathrm{~mL}$. Elemental analyses were obtained in-house. Unless otherwise noted, starting materials were obtained from commercial suppliers and used without further purification. $\left[\mathrm{Cu}\left(\mathrm{CH}_{3} \mathrm{CN}\right)_{4}\right] \mathrm{PF}_{6},{ }^{11}\left[\mathrm{Cu}(\mathrm{bpy})\left(\mathrm{PPh}_{3}\right)\right] \mathrm{Cl},{ }^{12}$ and $\left[\mathrm{Cu}\left(\mathrm{PPh}_{3}\right) \mathrm{Cl}\right]_{4}{ }^{13}$ were prepared according to literature procedures.

General procedure for preparation of oxaziridines. To a solution of the starting ketone (1.0 equiv) in toluene was added $1.2-2.0$ equiv of $\alpha$-methylbenzylamine ( $\tilde{\alpha} \mathrm{MBA})$, freshly crushed $5 \AA$ molecular sieves, and $5 \mathrm{~mol} \%$ of $p$-toluenesulfonic acid monohydrate. The reaction mixture was then refluxed in a three-necked round-bottom flask equipped with a water-cooled condenser and drying tube for ca. $48 \mathrm{~h}$. While the imine solution was cooling, a flame-dried round bottom flask kept under $\mathrm{N}_{2}$ atmosphere was charged with $m$-CPBA (1.2-2.0 equiv) and methylene chloride to completely dissolve the $m$-CPBA. The flask was cooled to $-78{ }^{\circ} \mathrm{C}$ and the imine solution was then transferred to the $m$-CPBA solution via a wide-bore cannula. The reaction was followed by TLC and was generally complete within one hour, at which time, it was quenched with saturated $\mathrm{Na}_{2} \mathrm{~S}_{2} \mathrm{O}_{3}$ and allowed to warm to room temperature. The layers were separated, and the organic layer was washed with saturated $\mathrm{NaHCO}_{3}$, brine, and dried over $\mathrm{Na}_{2} \mathrm{SO}_{4}$. Concentration followed by column chromatography or medium-pressure liquid chromatography (MPLC) on silica gel with the indicated solvent system provided the oxaziridine.

General procedure for $\mathrm{Cu}(\mathrm{I})$ or $\mathrm{Fe}(\mathrm{II})$ promoted cyclization (Table 2, Entry 4). The substrate concentration was fixed at $0.05 \mathrm{M}$, and $5 \mathrm{~mol} \%$ of catalyst was used in all cases. The following procedure is representative. A mixture of $\left[\mathrm{Cu}\left(\mathrm{CH}_{3} \mathrm{CN}\right)_{4}\right] \mathrm{PF}_{6}{ }^{11}(12 \mathrm{mg}, 0.032 \mathrm{mmol}$, 0.05 equiv) and degassed THF $(110 \mathrm{~mL})$ in a Schlenk-type reaction vessel was refluxed for 30 min under Ar atmosphere. To the resulting solution was transferred dropwise a solution of 2diphenylmethyl-3-phenyl-3-(1'-phenyl-5'-hexen-1'-yl)oxaziridine 12 (246 mg, $0.642 \mathrm{mmol})$ in degassed THF (15 mL plus $5 \mathrm{~mL}$ rinse) via a cannula over a 5 min period. Refluxing was continued for an additional $20 \mathrm{~h}$. After cooling to room temperature, the solvent was carefully evaporated. Column chromatography of the residue using pentane afforded $78 \mathrm{mg}(76 \%)$ of a colorless oil whose composition was assigned as a 20:70:10 mixture of cis and trans-1-phenyl-2methylcyclopentane 13a,b and 1,2,3,3a,8,8a-hexahydrocyclopent[a]indene $\mathbf{1 4}$ by ${ }^{1} \mathrm{H}-\mathrm{NMR}$ integration. This mixture was chromatographically (TLC) inseparable, and the products thus obtained were identical in all respects with the authentic samples prepared as reported below. 


\section{Compound characterization}

Compounds 1 and 3 have been previously described. ${ }^{5}$

$N$-(S)- $\alpha$-methylbenzyl-3-pentenylamide (2). According to the general procedure, $\left[\mathrm{Cu}\left(\mathrm{PPh}_{3}\right) \mathrm{Cl}\right]_{4}(0.05$ equiv) in dry THF was reacted with oxaziridine 5 (1 equiv). The reaction mixture was refluxed for $7 \mathrm{~h}$. Column chromatography with 1:3 ethyl acetate/hexane afforded the title compound as light yellow oil. $R_{f} 0.22$ (1:3 ethyl acetate/hexane); ${ }^{1} \mathrm{H}$ NMR (300 MHz, $\left.\mathrm{CDCl}_{3}\right) \delta 1.46(\mathrm{~d}, J=6.9 \mathrm{~Hz}, 3 \mathrm{H}), 2.24(\mathrm{~m}, 2 \mathrm{H}), 2.37(\mathrm{~m}, 2 \mathrm{H}), 4.97(\mathrm{q}, J=6.9 \mathrm{~Hz}, 1 \mathrm{H}), 5.05(\mathrm{~m}$, 2H), $5.80(\mathrm{~m}, 1 \mathrm{H}), 5.99$ (br. s, $1 \mathrm{H}), 7.28(\mathrm{~m}, 5 \mathrm{H}) ;{ }^{13} \mathrm{C} \mathrm{NMR}\left(74.5 \mathrm{MHz}, \mathrm{CDCl}_{3}\right) \delta 21.8,29.7$, 35.9, 48.7, 115.6, 126.2, 127.3, 128.6, 137.1, 143.3, 171.4; IR ( $\left.\mathrm{CCl}_{4}\right) 3420,3295,3030,3015$, 2968, 2925, 1740, 1640, 1540, 1492, 1450, 1372, $1240 \mathrm{~cm}^{-1}$; MS (CI) m/e $221\left(\mathrm{M}^{+}+\mathrm{NH}_{4}{ }^{+}\right), 204$ $\left(\mathrm{M}^{+}+1\right)$; Anal. calcd for $\mathrm{C}_{13} \mathrm{H}_{17} \mathrm{NO}$ : C, 76.81; H, 8.43; N, 6.89; found: $\mathrm{C}, 76.60 ; \mathrm{H}, 8.40 ; \mathrm{N}, 6.70$.

Racemic-3-(3'-butenyl)-3-methyl-2-(1'-phenylethyl)oxaziridine (4). According to the general procedure, commercially available 5-hexen-2-one $(10.0 \mathrm{~g}, 0.11 \mathrm{~mol})$ was reacted with racemic $\alpha$-MBA (16.0 g, $0.15 \mathrm{~mol})$ followed by oxidation with $m$-CPBA $(30 \mathrm{~g}, 0.13 \mathrm{~mol})$. Column chromatography with 3:97 ethyl acetate/hexane afforded the title compound as a mixture of two diastereomers. Fractional distillation gave 4a $\left(3.41 \mathrm{~g}, 14 \%\right.$ yield). $R_{f} 0.48$ (10\% ethyl acetate/hexane); ${ }^{1} \mathrm{H}$ NMR $\left(300 \mathrm{MHz}, \mathrm{CDCl}_{3}\right) \delta 1.42(\mathrm{~s}, 3 \mathrm{H}), 1.48(\mathrm{~d}, J=6.6 \mathrm{~Hz}, 3 \mathrm{H}), 1.81-2.32$ $(\mathrm{m}, 4 \mathrm{H}), 3.03(\mathrm{q}, J=6.6 \mathrm{~Hz}, 1 \mathrm{H}), 4.85(\mathrm{~m}, 2 \mathrm{H}), 5.68(\mathrm{~m}, 1 \mathrm{H}), 7.35(\mathrm{~m}, 5 \mathrm{H}) ;{ }^{13} \mathrm{C}$ NMR $(74.5$ $\left.\mathrm{MHz}, \mathrm{CDCl}_{3}\right) \delta 16.0,23.1,28.5,38.6,62.6,84.0,114.7,127.1,127.6,128.6,137.6,141.2 ; \mathrm{MS}$ (CI) m/e $218\left(\mathrm{M}^{+}+1\right), 120,111,105$; Anal. calcd for $\mathrm{C}_{14} \mathrm{H}_{19} \mathrm{NO}$ : $\mathrm{C}, 77.38 ; \mathrm{H}, 8.81 ; \mathrm{N}, 6.44$; found: $\mathrm{C}, 77.69 ; \mathrm{H}, 9.01 ; \mathrm{N}, 6.30$. For compound $4 \mathbf{b}$ ( $4.15 \mathrm{~g}, 17 \%$ yield): $R_{f} 0.48$ (10\% ethyl acetate/hexane); ${ }^{1} \mathrm{H}$ NMR $\left(300 \mathrm{MHz}, \mathrm{CDCl}_{3}\right) \delta 1.41(\mathrm{~s}, 3 \mathrm{H}), 1.58(\mathrm{~d}, J=6.4 \mathrm{~Hz}, 3 \mathrm{H}), 1.73(\mathrm{~m}$, $1 \mathrm{H}), 1.90(\mathrm{~m}, 2 \mathrm{H}), 2.05(\mathrm{~m}, 1 \mathrm{H}), 3.66(\mathrm{q}, J=6.4 \mathrm{~Hz}, 1 \mathrm{H}), 4.97(\mathrm{~m}, 2 \mathrm{H}), 5.72(\mathrm{~m}, 1 \mathrm{H}), 7.37(\mathrm{~m}$, $5 \mathrm{H}) ;{ }^{13} \mathrm{C}$ NMR $\left(74.5 \mathrm{MHz}, \mathrm{CDCl}_{3}\right) \delta 23.5,23.6,29.6,30.5,62.0,84.3,115.2,126.8,127.6$, 128.7, 137.2, 141.6.

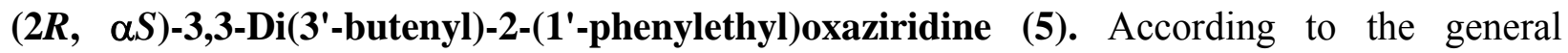
procedure, 1,8-nonadien-5-one ${ }^{14}(0.200 \mathrm{~g}, 1.45 \mathrm{mmol})$ was reacted with $(S)$ - $\alpha$-MBA $(0.350 \mathrm{~g}$, $2.90 \mathrm{mmol})$ followed by oxidation with $m$-CPBA $(0.500 \mathrm{~g}, 2.90 \mathrm{mmol})$. Column chromatography with 3:97 ethyl acetate/hexane afforded the title compound as a light yellow oil $(0.269 \mathrm{~g}, 72 \%$ yield). $R_{f} 0.58\left(10 \%\right.$ ethyl acetate/hexane); ${ }^{1} \mathrm{H}$ NMR $\left(300 \mathrm{MHz}, \mathrm{CDCl}_{3}\right) \delta 1.56(\mathrm{~d}, J=6.6 \mathrm{~Hz}$, $3 \mathrm{H}), 1.77-2.40(\mathrm{~m}, 8 \mathrm{H}), 3.66(\mathrm{q}, J=6.4 \mathrm{~Hz}, 1 \mathrm{H}), 4.88(\mathrm{~m}, 4 \mathrm{H}), 5.72(\mathrm{~m}, 2 \mathrm{H}), 7.35(\mathrm{~m}, 5 \mathrm{H}),{ }^{13} \mathrm{C}$ NMR $\left(74.5 \mathrm{MHz}, \mathrm{CDCl}_{3}\right) \delta 23.8,28.6,28.8,29.9,35.8,62.3,86.3,115.1,127.4,128.1,128.9$, 129.1, 137.6, 138.1, 141.7; IR $\left(\mathrm{CCl}_{4}\right) 3035,2965,2920,1635,1445,980 \mathrm{~cm}^{-1}$; MS (EI) m/e 258 $\left(\mathrm{M}^{+}+1\right), 240,202,186,166,136,125,105,77,55$; HRMS calcd for $\mathrm{C}_{17} \mathrm{H}_{23} \mathrm{NO}: \mathrm{M}^{+}=257.1778$; found: $\mathrm{M}^{+}=257.1783$.

(2R, 3R, $\alpha S)$-3-(3'-Butenyl)-3-isopropyl-2-(1'-phenylethyl)oxaziridine (6). According to the general procedure, 2-methyl-6-hepten-3-one ${ }^{15}(0.400 \mathrm{~g}, 3.17 \mathrm{mmol})$ was reacted with $(S)-\alpha-$ MBA $(0.600 \mathrm{~g}, 5.00 \mathrm{mmol})$ followed by oxidation with $\mathrm{m}$-CPBA $(0.706 \mathrm{~g}, 3.80 \mathrm{mmol}, 1.2$ equiv). Column chromatography with 3:97 ethyl acetate:hexane afforded the title compound as a 
light yellow oil (0.205 g, 27\% yield). $R_{f} 0.54$ (10\% ethyl acetate/hexane); ${ }^{1} \mathrm{H}$ NMR (300 MHz, $\left.\mathrm{CDCl}_{3}\right) \delta 0.80(\mathrm{~d}, J=5.4 \mathrm{~Hz}, 3 \mathrm{H}), 0.83(\mathrm{~d}, J=7.0 \mathrm{~Hz}, 3 \mathrm{H}), 1.55(\mathrm{~d}, J=6.3 \mathrm{~Hz}, 3 \mathrm{H}), 1.76-1.81$ $(\mathrm{m}, 3 \mathrm{H}), 2.07(\mathrm{~m}, 1 \mathrm{H}), 2.15(\mathrm{~m}, 1 \mathrm{H}), 3.57(\mathrm{q}, J=6.4 \mathrm{~Hz}, 1 \mathrm{H}), 4.96-5.05(\mathrm{~m}, 2 \mathrm{H}), 5.75-5.84(\mathrm{~m}$, 1H), 7.25-7.37 (m, 5H); ${ }^{13} \mathrm{C}$ NMR (125.5 MHz, $\left.\mathrm{CDCl}_{3}\right) \delta 16.6,17.3,23.5,26.3,30.1,33.7,61.9$, 88.2, 114.9, 127.0, 127.5, 128.5, 137.5, 141.5; IR ( $\left.\mathrm{CCl}_{4}\right)$ 2945, 2925, 1585, 1420, 1365, 1235 , 1130, $1005 \mathrm{~cm}^{-1}$; MS (EI) m/e $245 \mathrm{M}^{+}, 228,214,202,186,172,162,138,120,104,77$; $[\alpha]_{\mathrm{D}}-$ 18.1 ( $c=0.5$, methanol); Anal. calcd for $\mathrm{C}_{16} \mathrm{H}_{23} \mathrm{NO}$ : C, 78.32; H, 9.45; N, 5.71; found: C, 78.70; $\mathrm{H}, 9.80 ; \mathrm{N}, 6.10$.

(2R, 3S, $\alpha S)$-3-Benzyl-(3'-butenyl)-2-(1'-phenylethyl)oxaziridine (7a) and (2R, 3R, $\alpha S)-3-$ Benzyl-(3'-butenyl)-2-(1-phenylethyl)oxaziridine (7b). According to the general procedure, 1phenyl-5-hexen-2-one ${ }^{16}(0.3 \mathrm{~g}, 1.72 \mathrm{mmol})$ was reacted with $(S)$ - $\alpha$-MBA $(0.313 \mathrm{~g}, 2.58 \mathrm{mmol}$ 1.5 equiv) followed by the oxidation with $m$-CPBA $(0.550 \mathrm{~g}, 2.72 \mathrm{mmol})$. Column chromatography with 1:1 benzene:hexane afforded the title compound (a mixture of two diastereomers) as an oil. Further chromatography with 2:98 ethyl acetate:hexane allowed for the partial separation of the two major diastereomers. For diastereomer 7a $(0.120 \mathrm{~g}, 24 \%$ yield $): R_{f}$ 0.51 (50\% benzene/hexane); ${ }^{1} \mathrm{H}$ NMR $\left(300 \mathrm{MHz}, \mathrm{CDCl}_{3}\right) \delta 1.25(\mathrm{~m}, 2 \mathrm{H}), 1.56(\mathrm{~d}, J=6.4 \mathrm{~Hz}$, $3 \mathrm{H}), 1.75(\mathrm{~m}, 1 \mathrm{H}), 1.90(\mathrm{~m}, 1 \mathrm{H}), 2.98(\mathrm{dd}, J=7.9,6.9 \mathrm{~Hz}, 2 \mathrm{H}), 3.79$ (q, $J=6.4 \mathrm{~Hz}, 1 \mathrm{H}), 4.72$ $(\mathrm{m}, 2 \mathrm{H}), 5.51(\mathrm{~m}, 1 \mathrm{H}), 7.06-7.42(\mathrm{~m}, 10 \mathrm{H}) ;{ }^{13} \mathrm{C} \mathrm{NMR}\left(75.4 \mathrm{MHz}, \mathrm{CDCl}_{3}\right) \delta 23.4,28.3,34.9$, 35.6, 62.6, 114.6, 126.8, 127.3, 127.8, 128.6, 128.8, 129.6, 136.3, 137.7, 140.9; IR $\left(\mathrm{CCl}_{4}\right)$ 3060, 3020, 2965, 2920, 1645, 1490, 1448, 920, $700 \mathrm{~cm}^{-1}$; MS (CI) m/e $294\left(\mathrm{M}^{+}+1\right), 278,226,175$, $120 ;[\alpha]_{\mathrm{D}}-41.6$ (c=1.1, methanol); Anal. calcd for $\mathrm{C}_{20} \mathrm{H}_{23} \mathrm{NO}$ : $\mathrm{C}, 81.87 ; \mathrm{H}, 7.91 ; \mathrm{N}, 4.77$; found: C, 81.99; H, 8.30; N, 5.17. Diastereomer 7b $\left(0.139\right.$ g, 28\% yield): $R_{f} 0.56 \quad(50 \%$ benzene/hexane); ${ }^{1} \mathrm{H}$ NMR $\left(300 \mathrm{MHz}, \mathrm{CDCl}_{3}\right) \delta 1.65(\mathrm{~d}, J=6.0 \mathrm{~Hz}, 3 \mathrm{H}), 1.80-2.02(\mathrm{~m}, 3 \mathrm{H})$, $2.20(\mathrm{~m}, 1 \mathrm{H}), 2.95$ (dd, $J=6.9 \mathrm{~Hz}, 2 \mathrm{H}), 3.75$ (q, $J=6.3 \mathrm{~Hz}, 1 \mathrm{H}), 4.95(\mathrm{~m}, 2 \mathrm{H}), 5.70(\mathrm{~m}, 1 \mathrm{H})$, 7.20-7.40 (m, 10H); $\left.{ }^{13} \mathrm{C} \mathrm{NMR} \mathrm{(74.5} \mathrm{MHz,} \mathrm{CDCl}_{3}\right) \delta 23.0,27.4,29.5,43.3,62.0,87.0,115.3$, 126.6, 127.4, 127.8, 128.3, 128.6, 129.5, 135.8, 137.1, 140.7; IR ( $\left.\mathrm{CCl}_{4}\right)$ 3060, 3020, 2985, 2920, 1635, 1500, 1490, 1450, 910, $695 \mathrm{~cm}^{-1}$; MS (CI) m/e $294\left(\mathrm{M}^{+}+1\right), 204,120 ;[\alpha]_{\mathrm{D}}-43.2(\mathrm{c}=1.2$, methanol); Anal. calcd for $\mathrm{C}_{20} \mathrm{H}_{23} \mathrm{NO}$ : C, 81.87; H, 7.91; N, 4.77; found: C, 82.02; H, 8.18; N, 5.00 .

2-Oxo-6-phenyl-hexan-5-amine, tert-butyl amide (10). Following the general procedure, oxaziridine $4(0.500 \mathrm{~g}, 2.30 \mathrm{mmol})$ was reacted with $\left[\mathrm{Cu}\left(\mathrm{PPh}_{3}\right) \mathrm{Cl}\right]_{4}(0.041 \mathrm{~g}, 0.05$ equiv $)$. The reaction mixture was refluxed for $5 \mathrm{~h}$, and concentrated. The crude mixture was dissolved in dry pyridine $(4 \mathrm{ml})$, and pivaloyl chloride $(0.71 \mathrm{ml}, 5.76 \mathrm{mmol})$ was added. The resulting mixture was stirred at room temperature overnight, and diluted with methylene chloride. The organic phase was washed with $2 \mathrm{M} \mathrm{HCl}$ solution, saturated aqueous $\mathrm{NaHCO}_{3}$, brine, and dried over $\mathrm{Na}_{2} \mathrm{SO}_{4}$. The solution was concentrated and purified by flash column chromatography eluting with 250:20:1 methylene chloride:methanol:ammonium hydroxide to afford the title compound as a yellow solid $\left(0.14 \mathrm{~g}, 21 \%\right.$ yield): $\mathrm{mp} 81-82{ }^{\circ} \mathrm{C} ; R_{f} 0.5\left(250: 20: 1 \mathrm{CH}_{2} \mathrm{Cl}_{2}: \mathrm{MeOH}: \mathrm{NH}{ }_{4} \mathrm{OH}\right)$; ${ }^{1} \mathrm{H}$ NMR $\left(300 \mathrm{MHz}, \mathrm{CDCl}_{3}\right) \delta 1.08(\mathrm{~s}, 9 \mathrm{H}), 1.73(\mathrm{~m}, 2 \mathrm{H}), 2.11(\mathrm{~s}, 3 \mathrm{H}), 2.48(\mathrm{~m}, 2 \mathrm{H}), 2.78(\mathrm{~m}$, 2H), $4.05(\mathrm{~m}, 1 \mathrm{H}), 5.59$ (br d, 1H), $\left.7.23(\mathrm{~m}, 5 \mathrm{H}) ;{ }^{13} \mathrm{C} \mathrm{NMR} \mathrm{(125.7} \mathrm{MHz,} \mathrm{CDCl}_{3}\right)$ 27.4, 30.1, 
38.6, 40.6, 41.6, 50.3, 126.5, 128.4, 129.4, 137.8, 178.2, 209.1; IR ( $\left.\mathrm{CCl}_{4}\right) 3440,1710,1655 \mathrm{~cm}^{-}$ 1; MS (CI) m/e $276\left(\mathrm{M}^{+}+1\right), 184,174,100,91,82,57$. Anal. calcd for $\mathrm{C}_{17} \mathrm{H}_{27} \mathrm{NO}_{2}$ : C, 74.14: $\mathrm{H}$, 9.15; N, 5.08; found; C, 74.00; H, 9.00; N, 4.81. An additional 44\% of $\mathbf{9}^{17}$ was also isolated.

3-Phenyl-7-octen-2-one (11). A mixture of 3-phenyl-7-octen-2-one dimethylhydrazone ${ }^{18}$ (1.566 $\mathrm{g}, 6.41 \mathrm{mmol})$ and iodomethane $(2.0 \mathrm{~mL}, 32.1 \mathrm{mmol})$ was stirred for $48 \mathrm{~h}$ at $\mathrm{rt}$. An excess of iodomethane was removed under reduced pressure to afford crude 3-phenyl-7-octen-2-one trimethylhydrazonium iodide quantitatively, which was treated with pentane $(20 \mathrm{~mL})$ and $6 \mathrm{M}$ $\mathrm{HCl}(10 \mathrm{~mL})$. Vigorous stirring was continued for $3 \mathrm{~h}$ at $\mathrm{rt}$. The aqueous layer was extracted with pentane $(2 \times 20 \mathrm{~mL})$. The combined organic phases were washed with brine $(30 \mathrm{~mL})$ and dried over $\mathrm{Na}_{2} \mathrm{SO}_{4}$. Flash column chromatography (5\% EtOAc/hexane) afforded the title compound as a clear oil $(1.07 \mathrm{~g}, 83 \%)$ : ${ }^{1} \mathrm{H}$ NMR $\left(300 \mathrm{MHz}, \mathrm{CDCl}_{3}\right) \delta 1.21-1.37(\mathrm{~m}, 2 \mathrm{H}), 1.64-1.77(\mathrm{~m}, 2 \mathrm{H})$, $1.98-2.17(\mathrm{~m}, 2 \mathrm{H}), 2.05(\mathrm{~s}, 3 \mathrm{H}), 3.60(\mathrm{t}, J=7.4 \mathrm{~Hz}, 1 \mathrm{H}), 4.90-5.01(\mathrm{~m}, 2 \mathrm{H}), 5.68-5.81(\mathrm{~m}, 1 \mathrm{H})$, 7.14-7.36 (m, 5H); ${ }^{13} \mathrm{C}$ NMR (75.4 MHz, $\left.\mathrm{CDCl}_{3}\right) \delta 26.6,28.9,31.1,33.5,59.5,114.6,127.1$, 128.1, 128.8, 138.3, 138.9, 208.2; IR $\left(\mathrm{CCl}_{4}\right) 1715 \mathrm{~cm}^{-1}$; MS (EI) m/e $202\left(\mathrm{M}^{+}\right), 91$ (100); HRMS (FAB) calcd for $\mathrm{C}_{14} \mathrm{H}_{19} \mathrm{O}(\mathrm{M}+\mathrm{H}): 203.1436$, found 203.1446.

2-Diphenylmethyl-3-methyl-3-(1'-phenyl-5'-hexen-1'-yl)oxaziridine (12). According to the general procedure, 3-phenyl-7-octen-2-one (168 $\mathrm{mg}, 0.831 \mathrm{mmol})$ was reacted with diphenylmethylamine $(229 \mathrm{mg}, 1.25 \mathrm{mmol})$ in toluene $(7 \mathrm{~mL})$ followed by oxidation with $\mathrm{m}$ CPBA (216 mg, $1.25 \mathrm{mmol}$ ). Flash column chromatography (3-5\% EtOAc/hexane) afforded the title compound (226 mg, 71\%) as a pale yellow oil, which was a chromatographically (TLC) inseparable mixture of diastereomers in a 2:1 ratio (from $\left.{ }^{1} \mathrm{H} \mathrm{NMR}\right):{ }^{1} \mathrm{H} \mathrm{NMR}\left(300 \mathrm{MHz}, \mathrm{CDCl}_{3}\right.$ ) $\delta$ 1.14-1.34 (m, 2H), $1.40(\mathrm{~s}, 3 \mathrm{H}), 1.57-2.04(\mathrm{~m}, 4 \mathrm{H}), 4.63(\mathrm{~m}, 0.66 \mathrm{H}), 4.70(\mathrm{~s}, 0.34 \mathrm{H}), 4.88-$ $4.98(\mathrm{~m}, 2 \mathrm{H}), 5.60-5.79(\mathrm{~m}, 1 \mathrm{H}), 7.04-7.54(\mathrm{~m}, 15 \mathrm{H}) ;{ }^{13} \mathrm{C} \mathrm{NMR}\left(75.4 \mathrm{MHz}, \mathrm{CDCl}_{3}\right.$ ) (for major isomer) $\delta 13.5,26.7,28.5,33.7,53.9,70.3,86.8,114.5,126.7,127.1,127.4,127.7,128.1,128.3$, 128.4, 128.6, 128.7, 138.5, 139.4, 139.8, 142.1; IR (neat) 2920, $1490 \mathrm{~cm}^{-1}$; MS (EI) m/e 384 $\left(\mathrm{M}^{+}+1\right), 167$ (100); HRMS (FAB) calcd for $\mathrm{C}_{27} \mathrm{H}_{30} \mathrm{NO}(\mathrm{M}+\mathrm{H})$ 384.2327, found 384.2347. Anal. calcd for $\mathrm{C}_{27} \mathrm{H}_{29} \mathrm{NO}$ : C, 84.56; H, 7.62; N, 3.65. Found: C, 84.20; H, 7.58; N, 3.28.

1-Phenyl-2-methylcyclopentane (13a,b). To a round-bottom flask containing a mixture of $\mathrm{Li}$ (199 mg, $28.7 \mathrm{mmol}), \mathrm{NH}_{3}(36 \mathrm{~mL})$ and THF $(18 \mathrm{~mL})$ was added a solution of 1-phenyl-2methylcyclopentanol ${ }^{19}(1.585 \mathrm{~g}, 8.99 \mathrm{mmol})$ in THF $(18 \mathrm{~mL})$ over $10 \mathrm{~min}$ at $-78{ }^{\circ} \mathrm{C}$ under $\mathrm{Ar}$ atmosphere. After stirring for $10 \mathrm{~min}$, solid $\mathrm{NH}_{4} \mathrm{Cl}$ (ca. $2.2 \mathrm{~g}$ ) was cautiously added to discharge the blue color over a few minutes. $\mathrm{NH}_{3}$ was allowed to evaporate overnight. The residue was partitioned between brine and $\mathrm{Et}_{2} \mathrm{O}$ (each $50 \mathrm{~mL}$ ). The organic phase was dried over $\mathrm{Na}_{2} \mathrm{SO}_{4}$. Flash column chromatography (10\% EtOAc/hexane) yielded the unreacted alcohol (577 $\mathrm{mg}$, $36 \%$ ) and a mixture of cis and trans isomers ${ }^{20}$ (651 mg, 45\% yield): ${ }^{1} \mathrm{H} \mathrm{NMR}\left(300 \mathrm{MHz}, \mathrm{CDCl}_{3}\right)$ $\delta 0.57(\mathrm{~d}, J=7.1 \mathrm{~Hz}, 3 \mathrm{H}), 0.91(\mathrm{~d}, J=6.3 \mathrm{~Hz}, 3 \mathrm{H}), 1.26-2.45(\mathrm{~m}, 10 \mathrm{H}), 3.14(\mathrm{q}, 6 \mathrm{H}), 7.16-7.31$ $(\mathrm{m}, 10 \mathrm{H}) ;{ }^{13} \mathrm{C}$ NMR $\left(75.4 \mathrm{MHz}, \mathrm{CDCl}_{3}\right) \delta 16.2,18.6,23.3,23.9,29.0,33.4,34.8,35.4,38.2$, $43.0,49.2,54.5,125.5,125.8,127.5,127.8,128.2,128.4,143.5,145.4$; IR (neat) $2940,1445 \mathrm{~cm}^{-}$ 1; MS (EI) m/e $160\left(\mathrm{M}^{+}\right), 104(100)$. 
1,2,3,3a,8,8a-Hexahydrocyclopent[a]indene (14). This compound was prepared according to a literature procedure ${ }^{21}$ using 2-phenyl-1-cyclopentane carboxylic acid $^{22}$ as a starting material in 57\% yield (two steps): ${ }^{1} \mathrm{H}$ NMR $\left(500 \mathrm{MHz}, \mathrm{CDCl}_{3}\right) \delta 1.33-2.09(\mathrm{~m}, 6 \mathrm{H}), 2.67$ (dd, $J=2.9,16.5$ $\mathrm{Hz}, 1 \mathrm{H}), 2.86(\mathrm{~m}, 1 \mathrm{H}), 3.21(\mathrm{dd}, J=8.9,16.5 \mathrm{~Hz}, 1 \mathrm{H}), 3.63(\mathrm{dt}, J=2.9,8.6 \mathrm{~Hz}, 1 \mathrm{H}), 7.15$ (s, $4 \mathrm{H}) ;{ }^{13} \mathrm{C}$ NMR $\left(75.4 \mathrm{MHz}, \mathrm{CDCl}_{3}\right) \delta 26.1,34.1,34.9,41.7,50.3,124.37,124.44,126.1,126.4$, 143.5, 148.0; IR (neat) 2930, 2850, 1475, $740 \mathrm{~cm}^{-1}$; MS (EI) m/e $158\left(\mathrm{M}^{+}\right), 129$ (100).

\section{Acknowledgements}

This work was supported by the Donors of the Petroleum Research Fund as administered through the American Chemical Society and the National Institutes of Health (GM-49093). YU thanks Osaka City University for granting a study leave.

\section{References and Footnotes}

1. Schmitz, E. Adv. Heterocyclic Chem. 1963, 2, 83. (b) Haddadin, M. J.; Freeman, J. P. In Oxaziridines, Hassner, A., Ed.; John Wiley: New York, 1985. (c) Davis, F. A.; Sheppard, A. C. Tetrahedron 1989, 45, 5703. (d) Davis, F. A.; Chen, B.-C. Chem. Rev. 1992, 92, 919. (e) Aubé, J. Chem. Soc. Rev., 1997, 26, 269.

2. Emmons, W. D. J. Am. Chem. Soc. 1957, 79, 5739. (b) Sakai, S.; Fujii, S.; Kitamura, M.; Iskii, Y. J. Polym. Sci., B, 1965, 3, 955. (c) Schmitz, E.; Murawski, D. Chem. Ber. 1965, 98, 2525. (d) Minisci, F.; Cecere, M.; Galli, R. Gazz. Chim. Ital. 1968, 98, 358. (e) Minisci, F.; Galli, R.; Cecere, M.; Malatesta, V.; Caronna, T. Tetrahedron Lett. 1968, 9, 5609. (f) Minisci, F.; Galli, R.; Malatesta, V.; Caronna, T. Tetrahedron 1970, 26, 4083. (g) Hawkins, E. G. E. J. Chem. Soc., Perkin Trans. 1, 1973, 2155. (h) Black, D. S. C.; Watson, K. G. Aust. J. Chem. 1973, 26, 2515. (i) Schmitz, E.; Streigler, H.; Heyne, H.-U.; Hilgetag, K.-P.; Dilcher, H.; Lorenz, R. J. Prakt. Chem. 1977, 319, 274. (j) Rivière, P.; Rivière-Baudet, M.; Richelme, S.; Satgé, J. Bull. Soc. Chim. Fr. 1978, 3-4 (pt. 2), 193. (k) Black, D. StC.; Blackman, N. A.; Johnstone, L. M. Aust. J. Chem. 1979, 32, 2041. (1) Suda, K.; Sashima, M.; Izutsu, M; Hino, F. J. Chem. Soc., Chem. Commun. 1994, 949. (m) Black, D. StC.; Edwards, G. L.; Laaman, S. M. Tetrahedron Lett. 1998, 39, 5853. (n) Stella, L. In Radicals in Organic Synthesis; Renaud, P., Sibi, M. P. Eds.; Wiley-VCH: New York, 2001; Vol. 2, pp 407-426.

3. Curran, D. P.; Porter, N. A.; Giese, B. Stereochemistry of Radical Reactions; VCH: Weinheim, 1995. (b) Newcomb, M. Tetrahedron 1993, 49, 1151.

4. Giese, B. Radicals in Organic Synthesis. Formation of Carbon-Carbon Bonds; Pergamon: Oxford, 1986. (b) Curran, D. P. Synthesis 1988, 417. (c) Motherwell, W. B.; Crich, D. FreeRadical Reactions in Organic Synthesis; Academic Press: London, 1992. 
5. Aubé, J.; Peng, X.; Wang, Y.; Takusagawa, F. J. Am. Chem. Soc. 1992, 114, 5466. (b) Aubé, J.; Gülgeze, B.; Peng, X. Bioorg. Med. Chem. Lett. 1994, 4, 2461. (c) Armstrong, A.; Draffan, A. G. J. Chem. Soc., Prekin Trans. 1, 2001, 2861.

6. Lowry, T. H.; Richardson, K. S. Mechanism and Theory in Organic Chemistry; 2nd Edn; Harper and Row: New York, 1987, pp 747 and 794 (and references therein).

7. For an example of hydrogen atom abstraction from THF, see: Yoshimitsu, T.; Tsunoda, M.; Nagaoka, H. Chem. Commun. 1999, 1745.

8. Walling, C.; Cioffari, A. J. Am. Chem. Soc. 1972, 94, 6064.

9. Beckwith, A. L. J.; Easton, C. J.; Lawrence, T.; Serelis, A. K. Aust. J. Chem. 1983, 36, 545. (b) Beckwith, A. L. J.; Schiesser, C. H. Tetrahedron Lett. 1985, 26, 373. (c) Spellmeyer, D. C.; Houk, K. N. J. Org. Chem. 1987, 52, 959. The calculations by Houk predict a 84:16 ratio of trans:cis for this radical. (d) Renaud, P. In Radicals in Organic Synthesis; Renaud, P., Sibi, M. P. Eds.; Wiley-VCH: New York, 2001; Vol. 1, pp 400-415.

10. Surzur, J.-M.; Stella, L. Tetrahedron Lett. 1974, 15, 2191. (b) Franz, J. A.; Barrows, R. D.; Camaioni, D. M. J. Am. Chem. Soc. 1984, 106, 3964. (c) Ishibashi, H.; Nakamura, N.; Ito, K.; Kitayama, S.; Ikeda, M. Heterocycles 1990, 31, 1781. (d) Ishibashi, H.; So, T. S.; Okochi, K.; Sato, T.; Nakamura, N.; Nakatani, H.; Ikeda, M. J. Org. Chem. 1991, 56, 95. (e) Motherwell, W. B.; Pennell, A. M. K. J. Chem. Soc., Chem. Commun. 1991, 877. (f) Bertrand, M. P.; Surzur, J.-M.; Oumar-Mahamat, H.; Moustrou, C. J. Org. Chem. 1991, 56, 3089. (g) Curran, D. P.; Abraham, A. C.; Liu, H. J. Org. Chem. 1991, 56, 4335. (h) Curran, D. P.; Morgan, T. M.; Schwartz, C. E.; Snider, B. B.; Dombroski, M. A. J. Am. Chem. Soc. 1991, 113, 6607. (i) Curran, D. P.; Liu, H. J. Am. Chem. Soc. 1992, 114, 5863. (j) Parsons, A. F.; Taylor, R. J. K. J. Chem. Soc., Chem. Commun. 1993, 224.

11. Kubas, G. J. Inorg. Synth. 1979,19, 90.

12. Barron, P. F.; Engelhardt, L. M.; Healy, P. C.; Kildea, J. D.; White, A. H. Inorg. Chem. 1988, 27, 1829.

13. Churchill, M. R.; Bezman, S. A.; Osborn, J. A.; Wormald, J. Inorg. Chem. 1972, 11, 1811.

14. Deslongchamps, P.; Rowan, D. D.; Pothier, N.; Saunde, J. K. Can. J. Chem. 1981, 59, 1122.

15. Kupin, B. S.; Petrov, A. A. Zh. Obshch. Khim. 1963, 33, 3860.

16. Trimitsis, G. B.; Hinkley, J. M.; Tenbrink, R.; Gustafson, G.; Erdman, J. J. Am. Chem. Soc. 1977, 99, 4838.

17. Hansen, A. L.; Skrydstrup, T. J. Org. Chem. 2005, 70, 5997. (b) Hu, X.-P.; Zheng, Z. Org. Lett. 2004, 6, 3585.

18. Eddaïf, A.; Laurent, A.; Mison, P.; Pellissier, N.; Carrupt, P.-A.; Vogel, P. J. Org. Chem. 1987, 52, 5548.

19. Descotes, G.; Fournier, M.; Mugnier, R. Bull. Soc. Chim. Fr. 1968, 3346. (b) Small, G. H.; Minella, A. E.; Hall, S. S. J. Org. Chem. 1975, 40, 3151.

20. Baldwin, J. E.; Bonacorsi, S. Jr. J. Am. Chem. Soc. 1993, 115, 10621.

21. Zimmerman, H. E.; Givens, R. S.; Pagni, R. M. J. Am. Chem. Soc. 1968, 90, 6096.

22. Bordwell, F. G.; Almy, J. J. Org. Chem. 1973, 38, 571. 